\title{
Impact of Human Resource Practices on Intention to Leave among Generation Z- The Future Workforce
}

\author{
Manesha Kodithuwakku (Corresponding author) \\ Graduate School of Management, Management \& Science University \\ 218, B, Bauddhaloka Mawathe, Colombo 07 Sri Lanka \\ E-mail:muncheeko@gmail.com
}

Mazuki Jusoh

Graduate School of Management, Management \& Science University

University Drive, Off Persiaran Olahraga, 40100 Shah Alam, Selangor, Malaysia

E-mail: keyjus@yahoo.com

\author{
Karuthan Chinna \\ Graduate School of Management, Management \& Science University \\ University Drive, Off Persiaran Olahraga, 40100 Shah Alam, Selangor, Malaysia \\ E-mail: karuthan@gmail.com
}

Received: Oct. 31, 2018 Accepted: Nov. 20, 2018 Online published: Nov. 27, 2018

doi:10.5296/ijhrs.v8i4.13845 URL: https://doi.org/10.5296/ijhrs.v8i4.13845

\begin{abstract}
The purpose of this research is to assess the impact of human resource practices on intention to leave with a mediating impact of job satisfaction among the Generation $\mathrm{Z}$ with respect to the telecommunication sector of Sri Lanka. Employees are the most valuable asset for any organization and making them feel satisfied and retaining them at work has become the key challenge for many companies. A study was conducted with the sample of 308 Generation $\mathrm{Z}$ employees working in the telecommunication sector. Exploratory Factor Analysis, Multiple Regression and Structural Equation Modeling were applied with use of SPSS and AMOS to analyze the relationships of these variables. Further, to reconfirm the findings interviews were conducted and data was gathers based on thematic analysis. However, having
\end{abstract}


flexibility was most significant among all the factors which led to job satisfaction among these young employees and job satisfaction has a negative significant towards intention to leave. The outcomes of the survey results with imperial knowledge on the future workforce and how to gain employee engagement for better productivity for all organization.

Keywords: generation Z, human resource practices, flexibility, job satisfaction, intention to leave

\section{Introduction}

Generation Z described as those born between 1996 and 2010, the next generation of workforce which we know very little about to harness the best out of them. This new Generation $\mathrm{Z}$ workforce will be the majority of the working environment in the future, just as aging Baby Boomers will reach their retirement. Generation $\mathrm{Z}$ represents perhaps the most extreme generational swings the workplace has ever undergone. To be prosperous in an ever-evolving competitive market, it is vital that organizations know how their employees feel at work, and what their expectations (Tulgan, 2013). How to retain the new emerging workforce of generation $\mathrm{Z}$ and how certain human resources practices will make them feel satisfied will help many organizations to reach excellence in performance.

\section{Empirical Review}

The focused areas of literature search were on the Intention to Leave and the factors leading towards it. However, literature on Generation $\mathrm{Z}$ and predictions about Generation $\mathrm{Z}$ workforce has been subsequently summarized.

\subsection{Generation Z}

Generation $\mathrm{Z}$ was predicted as better future employees by Hal Brotheim. He also states that they have the abilities required to make use of cutting-edge innovations. Brotheim contends that their vital attributes are their response to the new thoughts and distinct idea of flexibility which is distinguished any of the previous generations (Brotheim, 2014). Generation $\mathrm{Z}$ is been highlighted as mechanically clever and more corporative via web-based networking social media sites for their socializing (Vivier, 2017). Therefore, Generation Z is very much prepared for a worldwide business condition (Levit,2015). Another imperative detail is that Generation $\mathrm{Z}$ never look for only an occupation: they look for more than that. They need a sentiment of satisfaction and energy in their activity that helps advance the world (Williams, 2015). Generation Z, the cohort after the millennials, have already started working in the corporate arena and retaining them has become a challenge already. Based on the study by Rainmaker Thinking's in USA, after twenty years of ongoing workplace research since 1993, it is manifest that the emerging young workforce is lack of non-technical soft skills. The fundamental of personal responsibility, time management, interpersonal communication and problem solving are also missing in the new generation $\mathrm{Z}$ workforce. Employers are now discovered that it is worth their while to invest heavy in creating a workplace culture of highly defined behavioral norms. This new emerging Generation $\mathrm{Z}$ workforce will fill up the workplace in the next years to come, just as aging Baby Boomers are expected to step down (Tulgan, 2013). 
Globalization and the advancement in technology has meant that majority of the young generation qualify in technology related fields with the intention of finding a beneficial and satisfying job in the industry relevant. Most of the Generation $\mathrm{Z}$ employees are currently being absorbed by the telecommunication sector companies. Telecommunication companies provide the backbone, support and facilitate all the other sectors and growth of the country. However, retaining the young talent has become a real challenge for the telecommunication companies (Central bank Sri Lanka, 2017). Human capital problems have consistently occurred in many industries where the new youth workforce is concerned. As identified by Zak Stambor the company's best asset is employees, and retaining them has become a challenge to many organizations. Job satisfaction phenomenon is vital in the industry to increase productivity among the Generation Z (Stambor.Z . Monitor S, 2006)

\subsection{Intention to Leave}

Intention to leave has become a burning issue which impacts the growth and success of an organization. Despite the turnover of employees which is such a serious problem globally, and the many studies that have been done to investigate same, employee turnover has not reduced. High turnover and cost of replacing the employees results in reduction in productivity and poor quality of products and services (Rizwan, 2014). Employee Turnover Intention (ETO) by Maria Osteraker in 1999 suggested that the success of organization depends on two basic aspects which are employees' satisfaction and retention (Osteraker,1991). Sahin exposed that there is a negative relationship between job satisfaction and employee turnover intention (Faruk, 2011). Most of the previous studies on intention to leave, are done on Generations $\mathrm{X}$ and $\mathrm{Y}$, therefore, facts about Generation $\mathrm{Z}$ is not much known at the moment.

\subsection{Job Satisfaction}

For Generation Z, happiness is important and, if they can't enjoy this satisfaction at the work place, their goal is to leave the existing job (Ozkan. M, Solmaz.B, 2015). Locke in 1976 defined job satisfaction as a pleasurable or positive emotional state resulting from one's job or job experiences. Job Satisfaction has a significant association with several variables such as work performance and intention to leave (Locke, E. A.1976). Furthermore, job satisfaction can moderately mediate the association of personality variables and work behaviors (Mount M. Ilies. R.,Johnson, E. 2006). An imperative finding for any company to note is that job satisfaction has a relatively weak correlation to productivity (Judge, T. A., Locke, E. A., \& Durham, C. C. 1997). Human resource practices lead to job satisfaction (Mustafa. C et al 2014). However, job satisfaction among the Generation $Z$ as a working population revealed what really leads to satisfaction and to remain in an organization.

\subsection{Human Resource (HR) Practices}

A number of diverse factors can affect employee turnover. These contain the internal structure of the organization, career progression opportunities, recruitment policies and strategies, rewards and benefits, and training and development (Fitz-en.J, 1990). As supported by Lee (Lee. M, 2008) the effect of HRM practices on business performance such as training and development, compensation, teamwork, HR planning, regular 
performance appraisal and employee security leads to increase in firms' business performance and employee's productivity, product quality and the firm's flexibility. The main goal of HRM is to ensure that an organization is able to accomplish success through utmost important resources: its employees (Storey, 1992). Generation Z has distinct expectations of their employers. To again attention from this generation, and to retain them, organizations must re-assess key elements of their organization. Offering flexible and unique career advancement opportunities are essential to attract and retain this generation (Buhler P M, Evans N, 2018).

Pragmatic evidence from a study done representing a sample of European employees shows that there is a positive correlation between functional flexibility and job satisfaction (Origo, Pagani, 2008). A study done in Jordan revealed that flexibility leads to job satisfaction. Also, another finding indicates that firms' management should consider offering job flexibility in their efforts to attracts and retain talented employees and to result in a committed workforce (Rawashdeh. A M Almasarweh. M. S,. \& Jaber. J, 2016). Another important area is training. However, the quality of training provided to employees has an indirect correlation with employees' intention to stay or quit the organization. Shoaib in his study reveals that the main root behind organization's success is training provided to the employees. Organizations should highlight more on effective training programs which are useful and necessary for organizations to retain their skilled employees and reduce turnover rate. Also, no organization can secure success until and unless management takes care of turnover rate effectively and efficiently (Shoaib M., Noor A., Tirmizi SR., Bashir S. 2009). Professional development opportunities can be substituted when career advancement is not available among the generation $\mathrm{Z}$. However, Gen Z must be constantly challenged (Creswell 2009).

Effective operation of human resource (HR) practices appears to depend on supervisors' active involvement in the intervention process. Supervisor support refers to the supervisor's behavior in helping their employees to demonstrate the knowledge, skills and attitudes (Miles, Huberman, 1994). A study done in Malaysia indicated that the critical significance between supervisory support and job satisfaction (Rhoades, Eisenberger, Armeli, 2001). Whist generation $\mathrm{Z}$ has always been identified as independent, still the awareness about how they will react to supervisory support has not yet been researched.

\section{Conceptual Framework}

Considering the most important factors of HR practices leading to job satisfaction when considering Generation $\mathrm{Z}$ is been captured to develop the conceptual framework and job satisfaction is considered as a mediator in the path of HR practices leading to intention to leave. 


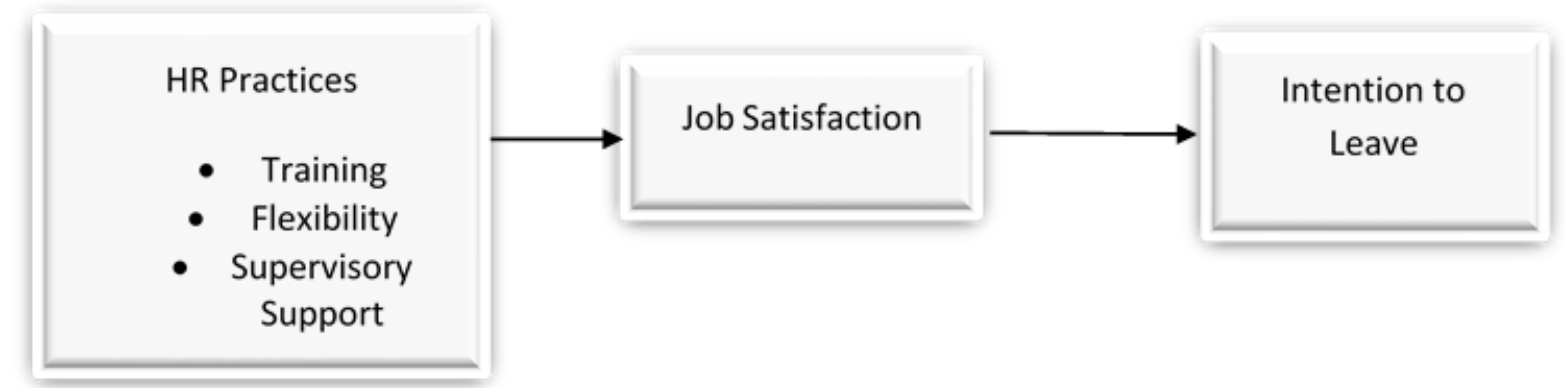

Figure 1. Conceptual Framework

\subsection{Research Hypothesis}

Based on the conceptual framework listed below are the hypothesis proposed

H1 There is significant association between HR practices and job satisfaction

$\mathrm{H} 2$ There is a significant association between job satisfaction and intention to leave

H3 Job Satisfaction mediates the relationship between HR practices and intention to leave

\subsection{Sub Hypothesis}

H1aThere is a relationship between training and job satisfaction

H1bThere is a relationship between supervisory support and job satisfaction

H1c There is a relationship between flexibility and job satisfaction

\section{Method}

The population for this study comprised all mobile telecommunication operators who provide voice and data solutions in Sri Lanka. Based on the Krejcie and Morgan in 1970 (Qureshi, 2017), the appropriate sample size is 300 . However, considering the $65 \%$ response rate (Sekaran, Bougie. 2010). 460 generation $\mathrm{Z}$ employees were selected through a simple random sampling method. A questionnaire was developed, tested and distributed among the generation $\mathrm{Z}$ employees in the telecommunication organizations. A quantitative methodology was used for data collection and analysis. A measuring instrument with 5-point likert scale was used to obtain responses. First, the descriptive statistics of the study explained the primary data of the analysis and then the regression analysis was carried out to analyze the relationships and then to determine the conceptual model of the study. The bootstrapping method was performed to measure the significant of the mediator impact. Subsequently, the hypotheses were tested, to emphasizing the relationship among HR practices, job satisfaction and intention to leave. Further, interviews were conducted to reassure the findings and thematic analysis were applied for better understanding.

When considering the demography of the target population, the majority of respondents were qualified with high education (Diploma 27.9, Bachelor's 41.9\%, Master's degree 9.7\%) and the majority were males with $59.7 \%$. 


\section{Results}

The standardized regression weights were used since they allow to compare directly the relative effect of each independent variable on the dependent variable (Crompton, H., Burke, D., Gregory, K. H., \& Gräbe, C.2016). The significance is based on the critical ratio (CR) of the regression estimate (Hair, 1998). Thus, when CR values are greater than or equal to 2.58, it indicates a 99 percent level of significance and establishing significance at $\mathrm{p}<0.05$ level.

\subsection{Direct paths}

The Table 1 presents the standardized regression estimates and the direct association between the study constructs.

Table 1. Results of the hypothesis testing

\begin{tabular}{|c|c|c|c|c|c|c|c|c|c|}
\hline Path & & & Нyро & & Estimate & S.E. & C.R. & $\mathrm{P}$ & Labe \\
\hline JS & $<--$ & TRAIN & $\mathrm{H}_{1} \mathbf{a}$ & $\begin{array}{l}\text { There is a relationship } \\
\text { between training and job } \\
\text { satisfaction }\end{array}$ & .157 & .029 & 5.396 & $* * *$ & .255 \\
\hline JS & $<---$ & FLEX & $\mathrm{H}_{1} \mathrm{c}$ & $\begin{array}{l}\text { There is a relationship } \\
\text { between flexibility and } \\
\text { job satisfaction }\end{array}$ & .186 & .032 & 5.783 & $* * *$ & .321 \\
\hline JS & $<---$ & SUP & $\mathbf{H}_{1} \mathrm{~b}$ & $\begin{array}{ll}\text { There is a } & \text { relationship } \\
\text { between } & \text { supervisory } \\
\text { support } & \text { and job } \\
\text { satisfaction } & \end{array}$ & .077 & .029 & 2.648 & .008 & .136 \\
\hline ITL & $<--$ & JS & $\mathbf{H}_{2}$ & $\begin{array}{l}\text { There is a significant } \\
\text { association between job } \\
\text { satisfaction and } \\
\text { intention to leave }\end{array}$ & -0.602 & 0.160 & -3.755 & $* * *$ & .414 \\
\hline
\end{tabular}

Accordingly, training, flexibility and supervisory support associate significantly and positively on job satisfaction standardized estimates: $0.157,0.186,0.077$, C.R. :5.396, 5.783, 2.648 .

Thus, Hypothesis $\mathrm{H}_{1} \mathrm{a}, \mathrm{H}_{1} \mathrm{~b}, \mathrm{H}_{1} \mathrm{c}$ were accepted

Further, job satisfaction associate significantly and negatively on intention to leave with a standardized estimate: -0.602 and C.R.: 3.755 .

Thus, Hypothesis $\mathrm{H}_{2}$ was accepted.

However, flexibility shows the highest association with job satisfaction and supervisory support the lowest when considering the $\mathrm{CR}$ values.

\subsection{Indirect Paths}

An indirect effect implies a causal hypothesis whereby an independent variable causes a mediating variable which, in turn, causes a dependent variable (Biswas, Giri, Srivastava. 2006). Results of the proposed model indicate that indirect paths were significant confirming the results through bootstrapping. 
Table 2. Mediation relationship

\begin{tabular}{l|l|l|l|l}
\hline $\begin{array}{l}\text { Job } \\
\text { satisfaction }\end{array}$ & $\begin{array}{l}\text { Supervisory } \\
\text { Support }\end{array}$ & Flexibility & Training & \\
\hline $\begin{array}{l}\text { Intention to } \\
\text { leave }\end{array}$ & -.047 & -.087 & -.075 & Lower 95\% confidence limit \\
\hline $\begin{array}{l}\text { Intention to } \\
\text { leave }\end{array}$ & .000 & -.029 & -.023 & Upper 95\% confidence limit \\
\hline $\begin{array}{l}\text { Intention to } \\
\text { leave }\end{array}$ & .045 & .002 & .002 & P-Value \\
\hline
\end{tabular}

Job satisfaction mediates supervisory support to intention to leave relationships with a p-value 0.045

Job satisfaction mediates flexibility to intention to leave relationships with a p-value 0.002

Job satisfaction mediates training to Intention to leave relationships with a p-value 0.002

Based on the results all hypothesis were revealed to be significant.

\subsection{Themetic Analysis}

Quantitative method was the focal method of this study to obtain various assessments on

the research objectives, however qualitative interviews were conducted among 22 respondents of Generation $\mathrm{Z}$ until the themes saturated from the same sample frame for further understanding of the resons leading towards intention to leave. The method of analysis chosen for this purpose was a qualitative approach of thematic analysis. Thematic analysis is a broadly used qualitative approach to analysing interviews. The conceptual framework of the thematic analysis was mainly built upon the theoretical positions of identifying, analysing, and reporting patterns (themes) within the data introduced by Braun and Clarke (2006).

The interviews were done among the Generation $\mathrm{Z}$ employees in the telecommuication sector and was analysed based on a three-stage standered procedure (Creswell, 2009; Miles \& Huberman, 1994). Arranging the data for analysis by recording, decreasing the data into themes through a focus process of coding and representing the data. The patterns were identified through a rigorous process of data familiarisation, data coding, and theme development and revision.

The analysis stemmed 9 foremost categories based on the counts the number of times sources refer to each category. The category most referred to was 'Challenging Job' and the least referred to was 'Salary'. Following Themes were formed as a result of the analysis reconfirming having a challenging job as the most significant to retaining in a organization. 


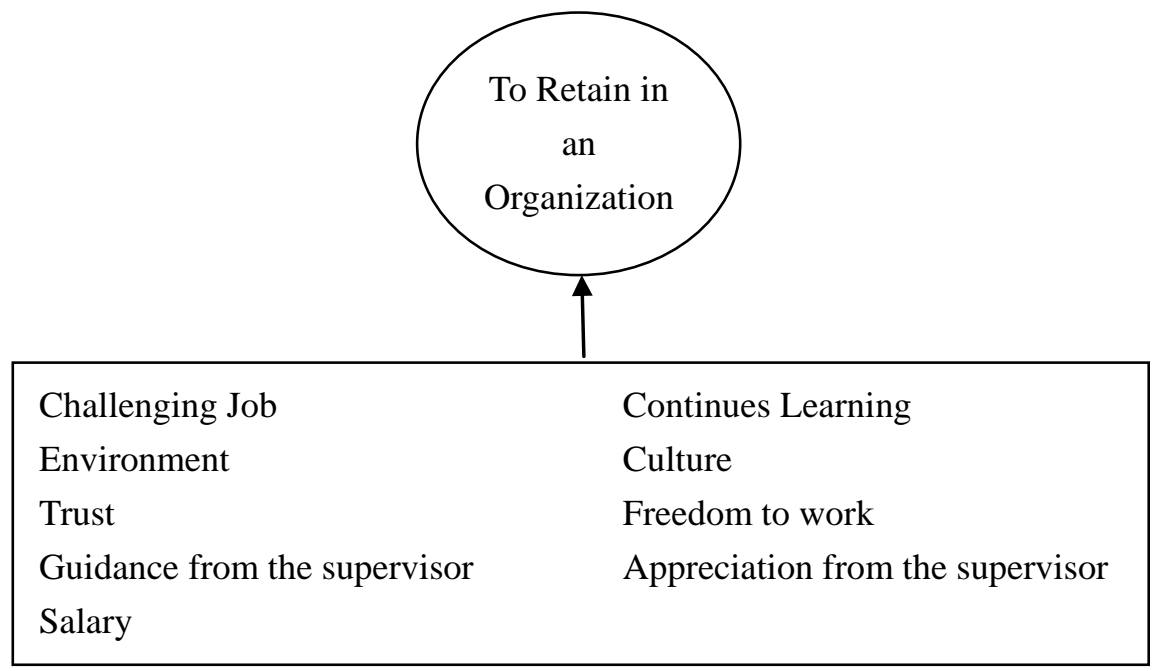

Figure 2. Themes

\section{Discussion}

The main objective of the study was to identify the HR practices associated with job satisfaction and intention to leave among the Generation $\mathrm{Z}$ in the telecommunication organizations. The empirical findings further reveal the HR practices impact on job satisfaction among the generation $\mathrm{Z}$.

The regression and SEM model specify diverse association among the variables in the model. The direction of parameter estimates shows impact and the effects on job satisfaction. All the four direct path associations were significant on job satisfaction and intention to leave among the Generation Z. When considering the HR practices, all the dimensions in this study such as supervisory support, flexibility and training all the associations with job satisfaction was revealed to be significant. Higher the supervisory support higher the job satisfaction. Higher the exposure for training, high the job satisfaction. Higher the flexibility on the job, higher the job satisfaction. However, flexibility at work was highlighted with the highest C.R rate associating with job satisfaction. This reveals that among the Generation $\mathrm{Z}$ employees, that they value more flexibility to perform better at work confirming the prediction of Hal Brotheim (Brotheim, 2014). Also, revealed that there is a negative association between job satisfaction and intention to leave and job satisfaction mediates the relationship between HR practices and intention to leave.

Further, revealed from the thematic analysis that having a challenging job leads to retaining of the generation $\mathrm{Z}$ employees and continues learning, environment, culture, trust, freedom to work, guidance from the supervisor, Appreciation from the supervisor and salary leads to satisfaction and retaining in the organization.

\section{Recommendations}

In an unavoidably competitive business platform, retaining your employees indeed is the biggest challenge. The young representatives of the generation $\mathrm{Z}$ have already started to leave the organizations as they entered to the corporate world. The findings from this study has examined what are the components of HR practices driving towards job satisfaction and 
intention to leave. Recorded below are the recommendations that can be arrived from the analysis.

Employee retention is dependent on what associations can offer to the employees and how employees could feel about the company based on the processes, benefits and environment. Findings of the study clearly shows that employees have expressed a preference for flexible working conditions and that leads to job satisfaction and then to negatively intention to leave. Flexibility can be incorporate in many ways. Flexi hours and work from home some options. Work life balance also contributes positively to job satisfaction. Encouraging employees to take vacations also would help to retain employees.

Enabling continues learning and personal development is essential for the organization as well as employees. It helps improve job satisfaction and retain employees. Also, it helps to improve quality of work, customer satisfaction, productivity, morale. The innovation, flexibility and dedication which are necessary to build a truly dynamic organization, comes from well-trained and supported employees. Professional development and training opportunities are the best ways to inspire and support individuals in an organization. In spite of Generation $\mathrm{Z}$ cooperative nature, most of young workforce would struggle in interacting face to face due to poor emotional intelligence. Managing this situation with success will be a challenge to many supervisors. Keeping up with technology and improving the relationship with the generation $\mathrm{Z}$ will add value to reach the best of them. Constantly encouraging them and guiding them to take challengers will definitely help the situation. Also energizing them and creating a positive enthusiastic environment will leads to gaining the best of the employees. Having a happy environment, learning opportunities and creating an appreciating culture will definitely leads towards retaining the staff. Making the generation $\mathrm{Z}$ workforce feel important and valuable part of the organization will lead to reach their full potential.

\section{Conclusion}

Generation $\mathrm{Z}$ the first digital generation, the generation that cannot even think about living without technology. The generation that expect technology to continuously increase their productivity. As they entered to the corporate world it has become a challenge to most organization due to the fact that the employers don't know much about the new workforce. (Levin,2018) Recommendation out of the finding on how to develop job satisfaction and retain the Generation $\mathrm{Z}$, the future workforce been highlighted mainly having more flexibility.

However, this study is mainly based on the quantitative study which may not focus on the important areas in understanding the needs and expectations of the Generation $\mathrm{Z}$ in an effective manner. With employee HR practices, continues research on employees needs and expectations to be carried out with special understa1nding to the work environment due to the continues change of needs. Future studies should include qualitative and quantitative approach on themes highlighted as important attributes to retaining the staff and to understand the future employees' better, to make them the best asset of the organization. 


\section{References}

Biswas, S., Giri, V. N., \& Srivastava, K. B. (2006). Examining the role of HR practices in improving individual performance and organizational effectiveness. Management and Labour Studies, 31(2), 111-133. https://doi.org/10.1177/0258042X0603100202

Brotheim, H. (2014). Introducing Generation Z. American Jail Association. Nov/Dec2014, 28(5), 15-20.

Buhler, P. M., \& Evans, N. (2018) Will Gen Z Want to Work for You? http://hrexecutive.com/will-gen-z-want-work/

Central bank Sri Lanka (2017). 2016 Annual Report of the Central Bank of Sri Lanka, Sri Jayawardanapura, Sri Lanka, Volume 1, Retrieved from: https://www.cbsl.gov.lk/en/publications/economic-and-financial-reports/annual-reports/annua l-report-2016

Creswell, J. W. (2009). Research design: qualitative, quantitative, and mixed methods approaches. Sage Publications

Crompton, H., Burke, D., Gregory, K. H., \& Gräbe, C. (2016). The Use of Mobile Learning in Science: A Systematic Review. Journal of Science Education and Technology, 25(2), 149-160. https://doi.org/10.1007/s10956-015-9597-x

Faruk, S. (2011). Affective Commitment As A Mediator of The Relationship Between Psychological Climate and Turnover Intention. World Applied Sciences Journal, 14(4), 523-530.

Fitz-en, J. (1990). Getting and Keeping Good Employees. In Personnel, 67, 25-29.

Hair Jr., J. F. et al. (1998). Multivariate Data Analysis with Readings. Englewood Cliffs, NJ Prentice-Hall.

Judge, T. A., Locke, E. A., \& Durham, C. C. (1997). The Dispositional Causes of Job Satisfaction: A Core Evaluations Approach. Research In Organizational Behavior, 19151

Lee, M. (2008). How Important is Education? Retrieved: www.uaseducation.com/articles/355/1/How-Important-is-Education/Page1.html

Levit, A. (2015). Make Way For Generation Z. The New York Times. ISSN 0362-4331.

Locke, E. A. (1976). The nature and causes of job satisfaction. In M.D. Dunnette (Ed.), Handbook of industrial and organizational psychology.1297-1343.

Miles, M. B., \& Huberman, A. M. (1994). Qualitative data analysis: an expanded sourcebook. Sage Publications

Mount, M., Ilies, R., \& Johnson, E. (2006). Relationship of Personality Traits and Counterproductive Work Behaviors: The Mediating Effects of Job Satisfaction. Personnel Psychology, 59(3), 591-622. https://doi.org/10.1111/j.1744-6570.2006.00048.x 
Mustafa, C. et al (2014). Human Resource Management Practices, Job Satisfaction and Organizational Commitment. International Journal of Academic Research in Business and Social Sciences.Retrieved www.researchgate.net/publication/268808633_Human_Resource_Management_Practices_Jo b_Satisfaction_and_Organizational_Commitment_Mustafa_Fedai_CAVUS

Origo, F., \& Pagani, L. (2008), Workplace flexibility and Job Satisfaction: some evidence from Europe. International Journal of Manpower, 29(6). https://doi.org/10.1108/01437720810904211

Osteraker, M. C. (1991)Measuring Motivation in A Learning Organization, Journal of Work Place Learning, Outcomes: An Australian Study. International Public Management Journal, $11(1)$.

Ozkan, M., \& Solmaz, B. (2015). The Changing Face of the Employees - Generation Z and their Perceptions of Work, Procedia. Economics and Finance, 26, 476-483. https://doi.org/10.1016/S2212-5671(15)00876-X

Qureshi, M. A. (2017). Impact of supervisor support on Job Satisfaction: a moderating role of fairness perception. Retrieved from: https://www.researchgate.net/publication/318779324_Impact_of_supervisor_support_on_job _satisfaction_a_moderating_role_of_fairness_perception

Rawashdeh, A. M., Almasarweh, M. S., \& Jaber, J. ( 2016). Do Flexible Work Arrangements Affect Job Satisfaction and Work-life Balance in Jordanian Private Airlines?, International Journal of Information, Business and Management, 8(3), 172-184.

Rhoades, L., Eisenberger, R., \& Armeli, S. (2001). Affective Commitment to The Organization: The Contribution of Perceived Organizational Support. Journal of Applied Psychology, 86- 82. https://doi.org/10.1037/0021-9010.86.5.825

Rizwan, M. (2014), International Journal of Human Resource Studies ISSN 2162-3058 2014, $4(3)$.

Sekaran, U., \& Bougie, R. (2010). Research Methods For Business: A Skill Building Approach (5th Ed.). West Sussex, UK: John Wiley \& Sons Ltd

Shoaib, M., Noor, A., Tirmizi, S. R., \& Bashir, S. (2009) Determinants of Employee Retention in Telecom Sector of Pakistan, 2nd CBRC, Lahore, Pakistan

Sobel, M. E. (1958). Effect analysis and causation in linear structural equation models, Psychometrika, 55, 495-515. https://doi.org/10.1007/BF02294763

Stambor, Z., \& Monitor, S. (2006). Vol 37, No. 3.

Storey, J. (1992). Development in the Management of Human Resources. Blackwell, Oxford

Tulgan, B. (2013). Meet Generation Z: The Second Generation Within The Giant "Millennial" Cohor; Http://Rainmakerthinking.Com/Assets/Uploads/2013/10/Gen-Z-Whitepaper.Pdf 
Vivier, T. L. (2017). You know that millennial word you keep throwing round... turns out you might actually be one. Here's why (Blog Post) Retrieved from https://www.goodthingsguy.com/lifestyle/generation-names/

Williams, A. (2015). Move Over, Millennials, Here Comes Generation Z, New York Times. Retrieved from https://www.nytimes.com/2015/09/20/fashion/move-over-millennials-here-comes-generationz.html

\section{Copyright Disclaimer}

Copyright for this article is retained by the author(s), with first publication rights granted to the journal.

This is an open-access article distributed under the terms and conditions of the Creative Commons Attribution license (http://creativecommons.org/licenses/by/4.0/). 